\title{
ЕКСПЕРИМЕНТАЛЬНИЙ СЦЕНІЧНИЙ ПРОСТІР: ПРОБЛЕМИ КЛАСИФІКАЦІЇ
}

\section{Катерина Юдова-Романова}

кандидат мистецтвознавства, доцент;

e-mail: iudovakateryna@gmail.com; ORCID: 0000-0003-2665-390X

Київський національний університет культури і мистецтв, Київ, Україна

\begin{abstract}
Анотація
Мета статті - дослідити, схарактеризувати та класифікувати експериментальні варіанти організації сценічного простору. У процесі дослідження було застосовано такі методи наукового пізнання: метод аналізу та синтезу інформації, культуролого-мистецтвознавчий метод (для встановлення зв'язку між варіантами форми сценічного простору та художньообразним рішенням вистави), а також історичний (для вивчення фактів з історії театру) та порівняльний (для визначення спільних і відмінних характеристик з метою класифікації сценічного простору). Метод синтезу й аналізу інформації використано для детального вивчення та подальшого аналізу досвіду втілення театральних вистав у експериментальному сценічному просторі. Завдяки поєднанню аналізу та синтезу забезпечується комплексний системний підхід до вивчення предмета дослідження - сценічного простору. У процесі дослідження проаналізовано літературні джерела вітчизняних і закордонних авторів з тематики роботи. Наукова новизна. Здійснено класифікацію сучасного експериментального сценічного простору за основними хронотопними характеристиками. Висновки. Зважаючи на фактологічний аналіз сучасних театральних практик, експериментальний сценічний простір відповідно до його часових і просторових характеристик можна класифікувати таким чином: щодо незмінності розташування на території протягом сталого часу - постійний (стаціонарний) і тимчасовий; щодо переміщення у процесі показу вистави - рухомий (мобільний) і нерухомий; щодо розміщення глядачів та виконавців - імерсійний і дискретний; щодо форми сценічного простору - закритий та відкритий (просто неба); способу розміщення сценічного майданчика щодопубліки - фронтальний, аренний, подіумний. Вісторіїтеатральнихприміщень трапляються непоодинокі випадки адаптації будівель нетеатрального призначення і навіть помешкань до показу вистав.
\end{abstract}

Ключові слова: експериментальний сценічний простір; альтернативний сценічний простір; нетрадиційний сценічний простір; сцена; театр; класифікація

\section{Вступ}

Протягом історії митці сцени - продюсери, постановники, виконавці й автори текстів - постійно прагнуть експериментувати не тільки зі сценічним утіленням 
Вісник Київського національного університету культури і мистецтв.

Серія: Сценічне мистецтво

задуму, а й з простором, де на очах глядачів відбувається сценічна дія. Протестні бажання, прагнення художньої новизни, пошуку, що часто-густо супроводжуються матеріально-економічною скрутою театральних колективів, штовхають митців до втілення сценічних постановок в експериментальному, альтернативному щодо традицій, не спроєктованому для показу вистав просторі. Так, наприклад, Пітер Брук, висловлюючись щодо художності театральних постановок, наголошував, що творчий пошук, митецька «іскра» може виникнути скоріш у експериментальному сценічному просторі, в якому існує «грубий» театр, а не «священний». «Чудове приміщення не завжди сприяє висіченню іскри, - писав П. Брук (2008, с.671), - тоді як випадковий зал стає чудовим місцем зустрічі, в цьому й полягає загадка театру, проте в розгадуванні цієї загадки єдина можливість перевести її в закономірність». Зрештою думку П. Брука підтримують й інші діячі театру. С. Ленглі (2000, с.72) вбачає причини парадоксу прагнення митців до постійного пошуку нових форм сценічного простору, у тяжінні до експериментів з ним і в менеджерській складовій сценічного мистецтва, в організації театральної справи: «Коли театри стають повністю заформалізованими і мають великий штат, - митці інстинктивно шукають інші місця роботи».

Сценічний простір - це комплексне явище, до характеристик якого, окрім архітектурно-просторових параметрів (місця розташування, форм і розміру сцени, місткості глядацької зали тощо) й історичних передумов створення, належать і показники матеріально-технічного забезпечення художньо-постановочних процесів освоєння митцями цього простору.

Так дослідники та практики театру - М. Г. Єдкін (1974), Ю. О. Мочалов (1981), В. І. Проскуряков (2002), О. Я. Ремес (1983), М. А. Френкель (1987) та інші - переважно розглядають сценічний простір суто як простір сцени, тобто майданчика, де розгортається дія в акторському виконанні, яку в режимі реального часу сприймає публіка. Такий підхід зумовлений насамперед тотожним розумінням сценічного простору як простору театральної вистави, в якому постановники та виконавці реальний простір сцени, переважно сцени-коробки, освоюють, переробляють і перетворюють у простір художній.

Питання сценічного простору та його технічного оснащення висвітлені в класичних роботах римського архітектора, механіка, ученого-енциклопедиста Вітрувія (1936); італійського архітектора-маньєриста пізнього Ренесансу, одного з провідних теоретиків архітектури своєї епохи Себастьяно Серліо (1600); Ніколо Саббаттіні (1638) - новатора й винахідника у сфері театральної архітектури та декорацій, освітлювальної та сценічної техніки, автора перших складних машин, пристроїв і механізмів для сцени, які створювали реалістичні візуальні та звукові ефекти; Йозефа Фурттенбаха $(1640,1628,1663)$ - німецького військового архітектора й інженера, який вивчав також і театральну архітектуру, особливості сценографії та способів створення декорацій, театрального освітлення та видовищних феєрверків. У першій половині XX ст. машиніст-механік Імператорського Олександрінського театру Ан. О. Петров (1910; 1903; 1925) та М. П. Ізвеков (1940) дослідили й описали технічні можливості сценічного простору та роль техніки в театральному видовищі.

В. В. Базанов (2005) вивчав еволюцію форм сценічного простору, а також театральної техніки та технологій в історично-практичній площині. В. Й. Берьоз- 
кін (2011; 2016a; 2016b) досліджував питання теорії та історії сценографії, що тісно пов'язані з питаннями сценічного простору. І. В. Ескузович $(2004$, с.35) фокусував свої дослідження на акустиці та звуковому забезпеченні сценічного простору. Автор цієї публікації К. В. Юдова-Романова комплексно в теоретичноісторичному та практичному ключі вивчає різні аспекти технічного забезпечення оформлення сценічного простору (2017b), зокрема ароматичного (2016, с.2936), піротехнічного (2018а, с.228-232), пневматичного (2017а, с.242-247), а також критично аналізує та мистецтвознавчо оцінює засоби пластичного оформлення сценічного простору в українському театрі XVII-XIX століть (2018b). Г. І. Веселовська (2019, с.34-36) розглядає комунікативну складову театрального мистецтва в контексті еволюції різних форм сценічного простору. В. І. Проскуряков (1986; 2001) послідовно, глибоко й системно досліджує генезу, тенденції формування типів, визначає принципи та розробляє методи проєктування українських театрів, звертаючись і до аспекту пересувних сценічних майданчиків. Американський науковець і театральний практик, автор праць з театрального менеджменту й організаційно-управлінської проблематики виконавського мистецтва С. Ленглі (2000, с.71-116) розглядає сценічний простір, «місце для вистав», як складову цілісної системи організації театральної справи у США.

Мета статті - дослідити, схарактеризувати та класифікувати експериментальні варіанти організації сценічного простору.

Отже, сьогодні можна стверджувати, що сценічний простір як об'єктивна умова організації сценічного дійства і самостійне мистецьке явище недостатньо вивчений.

\section{Виклад основного матеріалу}

Ставлячи за мету дослідження сценічного простору, варто зауважити, що історія театральної архітектури пов' язана з традиційними й експериментальними формами сценічних майданчиків. Традиційні театральні архітектурні форми попередньо виникали, зароджувалися з експериментальних форм та апробувалися протягом певного часу за допомогою експерименту. Митці для показу вистав прилаштовували нецільові з погляду театрального мистецтва приміщення, таким чином «нетеатральні майданчики перетворювались на місця і приміщення, призначені виключно для театру: ландшафти - на класичні театри Греції, готельні двори - на Елізабет-театри, собори та тенісні корти - на європейські театри XVIII століття» (Ленглі, 2000, с.71). Відбираючи експериментальним способом у кожну історичну епоху найкращі, найзручніші оптимальні з погляду експлуатації театральні приміщення, у театральній архітектурі викристалізовувалися та закріплювалися ті чи ті традиційні форми та сталі естетичні норми. Тому стає зрозумілим, чому сучасні театральні приміщення значною мірою мають у собі риси античних театрів, зокрема «використання відкритого простору, будівництво авансцени ближче до глядача, що додає спілкуванню більше інтимності» (Ленглі, 2000, с.71). Давньогрецьку традицію будувати театри у складі культових ансамблів з їх храмами, стадіонами, гімнасіями, скарбницями, священними джерелами, наприклад у Дельфах, простежуємо в появі у світі в другій половині XX століття багатопрофільних приміщень, що охоплювали театри та гімнастичні зали. 
Сучасні новозбудовані театри фактично продовжують традицію принципів побудови архітектурного простору, що вкорінилася ще у XIX столітті: сцена-коробка з оркестровою ямою, сцена-коробка з авансценою, сцена-коробка з розвиненою авансценою, в колі.

Етапи еволюції конфігураційних рішень стаціонарного сценічного простору в європейській театральній традиції від первісної форми до сучасних можна простежити на контурній схемі-малюнку (рис. 1) (McHenry ed., 1997, p.561). Ця класифікація видається цілком правомірною, а такі приміщення можуть відповідати критеріям традиційності, оскільки стали усталеною естетичною нормою.

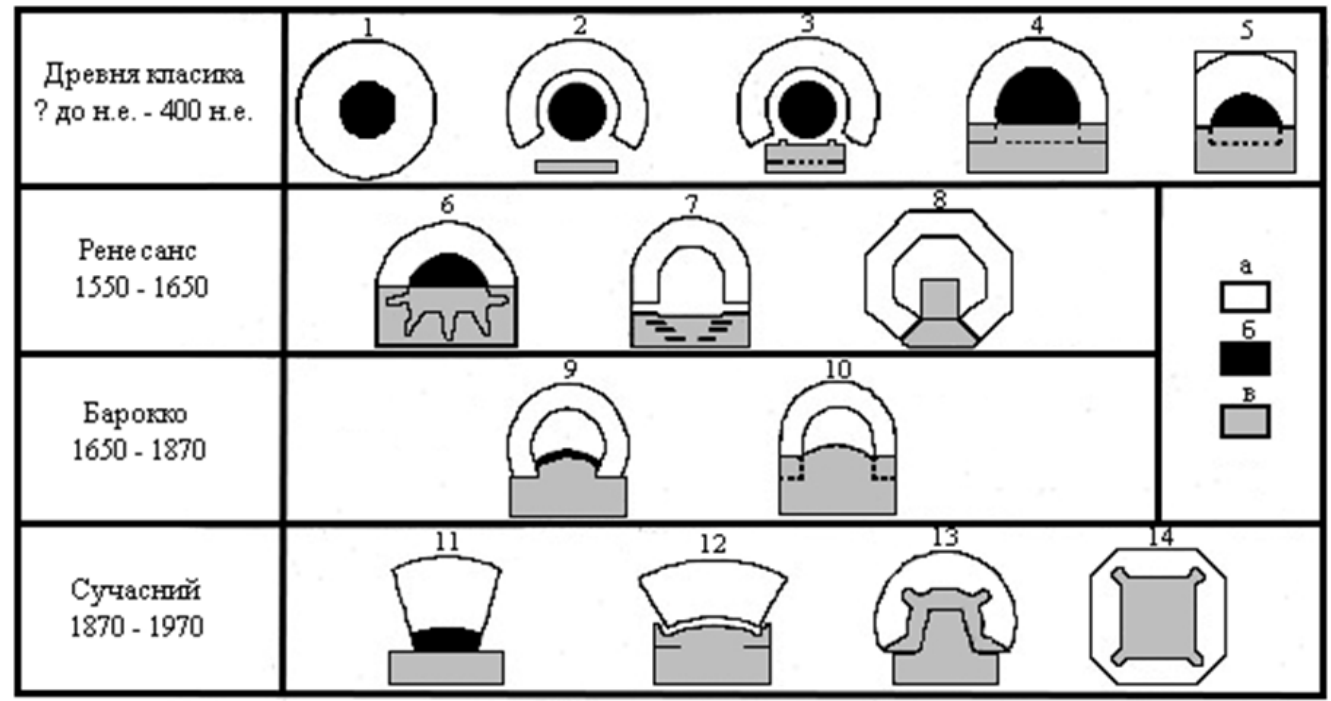

Рис. 1. Контурна схема-малюнок еволюції європейських театральних споруд

1. Первісна (Primitive)

2. Класична грецька (Greek Classical)

3. Грецька елліністична (Greek Hellenistic)

4. Римська (Roman)

5. Одеон (греко-римська) (Odium (Greco-Roman))

6. Множинної перспективи (Multiple vista stage)

7. Єдиної перспективи (Single vista stage)

8. Шекспірівська (Theatre of Shakespeare)

9. Підковоподібна (Horseshoe proscenium stag)

10. Театр Реставрації (Theatre of the Restoration)

11. Сцена-коробка з оркестровою ямою (Fan proscenium stage)

12. Сцена-коробка з авансценою (Fan proscenium-apron-caliper stage)

13. Сцена-коробка з розвиненою авансценою (Thrust stage)

14. В колі (In-the-round stage)
а. Зал для глядачів (Auditorium)
б. Оркестр (Orchestra)
в. Сцена (Stage) 
На запропонованій вище схемі подано традиційні форми організації стаціонарного театрального простору. Варто зауважити, що характерною рисою всіх цих стаціонарних театральних приміщень $€$ поділ архітектурного простору на зони: глядацьку та виконавську (площу сцени й оркестру).

Але паралельно з художнім освоєнням традиційного сценічного простору митці з різних об'єктивних чи суб'єктивних причин завжди намагалися шукати для втілення своїх творчих задумів (режисерських і сценографічних) альтернативу традиційним театральним підмосткам, експериментуючи з різними варіантами організації простору для показу вистав.

Пітер Брук у роздумах про закони та природу театру, викладених у збірці лекцій «Порожній простір», поруч із питаннями режисури, акторської майстерності, глядацькоїаудиторії, театрального менеджментунеобходить іпроблемитеатральноархітектурного простору й особливостей освоєння цього простору художникамисценографами. Для П. Брука потенційно сценічним простором, сценою може стати будь-який простір за умови, що в ньому рухається людина, яка спричиняє виникнення театральної дії, та на неї дивляться глядачі. Поняття «театр» у широкому розумінні, за П. Бруком (2008), асоціюється з червоною завісою, софітами, білим віршем, темрявою та певним набором саме театральної атрибутики: театральної каси, фоє, відкидних сидінь, рампи, зміни декорацій, антрактів і музики (с.623), люстр, що палають (с.671). Це перший традиційний вид архітектурносценічного простору для театральних вистав.

Другий вид - експериментальний або альтернативний, за П. Бруком, - «грубий театр». Характеризуючи народний театр як «грубий», режисер наголошував:

«Форми його [народного театру] змінювались від віку до віку, проте їх об'єднувала грубість. Сіль, піт, шум, запах - театр не в театрі, театр у повозках, на помостах; публіка, яка стоїть, п'є, сидить за столиками, включається в дію, подає репліки. Театр на задвірках, у мансардах, у сараях; підмостки зроблені на один вечір, рване простирадло, протягнуте через всю залу, зашарпана ширма, за якою наспіх переодягаються, - все це об'єднано загальним родовим поняттям Театр». (Брук, 2008, c.671)

П. Брук (2008, с. 697), простежуючи тенденції в розвитку театрального мистецтва, які багато в чому зумовлені часовими суспільними трансформаціями, дійшов висновку, що «сьогодні грубість ближче до життя, а святість далі від неї, ніж у будь-яку з епох».

У 1950-60-х роках у США як контрдія на зростання вартості бродвейських постановок зростає кількість позабродвейських театрів, а на початку 60-х років розгортається загальнонаціональний рух неприбуткових професіональних театрів. С. Ленглі наголошує: «В той час ця діяльність була відома під узагальненою назвою "експериментальний" театр, який асоціювався з неприбутковими театральними майданчиками типу церкви, горища, гаражів, кафе, ресторанів та вільних складських приміщень». Учений вважає, що «експериментальний аспект цього руху базувався скоріше на економічній необхідності, ніж на художніх цінностях» (Ленглі, 2000, с.71). Однак саме домінування в діяльності неприбуткових професіональних театрів експериментально-мистецької складової над 
Вісник Київського національного університету культури і мистецтв.

Серія: Сценічне мистецтво

комерційною робить їх найбільш творчо прогресивними, «дає найбільше можливостей для творчого пошуку» (Ленглі, 2000, с.27).

Сучасні театральні практики стрімко розвивають цей напрямок освоєння нетрадиційного, експериментального, альтернативного сценічного простору.

Валерій Пацунов (2018, с.15-19), розглядаючи експериментальний, альтернативний сценічний простір як детермінанту нової сценографічної лексики, наводить декілька прикладів з власного постановочного досвіду та із закордонних сценічних практик освоєння театральними митцями нетрадиційних, експериментальних сценічних майданчиків.

Створення лазерного та світлового шоу на гранях єгипетських пірамід та постановка опери «Аїда» Дж. Верді (1987 рік) на фоні пірамід Гізи та Великого Сфінкса відбувалися на сценічному просторі, який можна характеризувати як тимчасовий, дискретний, відкритий і фронтально розміщений щодо аудиторії.

Режисер-постановник В. Пацунов у тандемі з художником-постановником Д. Лідером задумували аналогічний за масштабом, але у вітчизняному історичному контексті проєкт сценічного втілення «Слова про Ігорів похід» на руїнах Успенського собору Києво-Печерської лаври. Сценічний простір постановники замислили також як тимчасовий, дискретний, відкритий, фронтально розміщений щодо глядачів. Примітно, що як і у прикладі застосовування руїн єгипетських пам'яток як фонових декорацій, так і у варіанті київських використовували світлові спецефекти: у Каїрі - лазерну техніку для створення шоу, у Києві - «місячне затемнення, що віщувало поразку Ігоревих військ, мало творитися у просторі неба за допомогою надпотужних авіаційних світлових прожекторів часів Другої світової війни, що функціонували на той час у аеропорту “Жуляни"» (Пацунов, 2018, с.17). Ескіз декорацій Д. Лідера (2004) з променями над руїнами собору опубліковано у збірці праць художника «Театр для себе».

Прикладом використання історичної пам'ятки архітектури XI століття - проїзду київських Золотих воріт - з метою створення стаціонарного (переважно саме тут відбувалися репертуарні вистави Київського театру поезії), нерухомого, дискретного, закритого, експериментального сценічного простору може слугувати постановка п'єси «Золоті ворота» за поемою Л. Горлача (Київський театр поезії, 1985, реж. В. Пацунов) (Липський, 1985).

Про освоєння експериментального сценічного простору, тимчасового, нерухомого, дискретного, закритого, фронтального, та особливості режисерськосценографічної лексики в ньому під час постановки вистави «Калігула» А. Камю (Київський театр «Золоті ворота», 1983 рік) на східцях столичного Національного центру ділового та культурного співробітництва «Український дім» згадує В. Пацунов (1993, с.8-9). Режисерові вдалося не просто вдало мізансценічно виправдати запропонований новий нетрадиційний східчастий сценічний простір, але й вибудувати у ньому засобами сценографії конфлікт - «один з найжорстокіших в історії людства імператорів Калігула катував своїх патриціїв на фоні величезного багряного панно: "Промова Леніна на III з'їзді комсомолу"» (Пацунов, 2018, c. 18).

Згодом режисерська фантазія дала змогу режисерові через проведення декількох репетицій перенести виставу «Калігула» на подіум Київського будинку 
моделей одягу. У такому разі ми можемо говорити про адаптацію постановки до дещо іншого сценічного простору - також тимчасового, нерухомого, дискретного, закритого, але не з фронтальним розміщенням глядачів, а комбінованим фронтально-подіумним. Пластичні зонги виконували напівоголені манекенниці в екстравагантних сукнях на подіумній ділянці сцени.

Продовжуючи режисерські експерименти з освоєння нових майданчиків для показу вистав, В. Пацунов ставить виставу в тимчасовому, нерухомому, дискретному, відкритому, аренного типу експериментальному сценічному просторі - на дереві: «Красуня сидить на високій вишні та збирає в кошик соковиті ягоди. До вишневого дерева підходить юнак на ходулях...» (Пацунов, 2018, с.19). Сценічна дія розвивається далі безпосередньо на дереві.

Іншим прикладом такого ж, але фронтального, експериментального сценічного простору може слугувати простір вистави «про злодіїв-грабіжників на вертикальній стіні реального триповерхового будинку з використанням вікон, канатів та [виконанням] карколомних трюків» (Пацунов, 2018, с.19).

Зразком постійного (але не стаціонарного), рухомого, імерсійного, просто неба та без будь-якого сценічного майданчика експериментального сценічного простору може слугувати спектакль-променад «Час» від компанії «U!Zahvati» режисерки П. Бараніченко. 2018 року національна компанія «U!Zahvati» запропонувала глядачам новий для нашої країни жанр - синтез екскурсії містом, радіовистави та театралізованої процесії. Вистава-променад, в анотації до якої написано: «Виводимо глядача із затяжної культурної коми», - привернула до себе увагу навіть людей, абсолютно далеких від театру. Зібравшись у Києві на Пішохідному мості, група з 35 осіб одягає навушники. Слухаючи гіда, вони починають маршрут. Пересуваються Києвом, де кожна будівля, вітрина, лавка завдяки аудіозапису трансформується зі звичних архітектурних форм у красномовну декорацію. Формат імерсійної вистави-променаду передбачає повне залучення глядачів у процес. Акторами вистави стають випадкові перехожі, а сценою - місто (U!Zahvati).

Прикладом тимчасового, рухомого, дискретного, закритого, фронтального експериментального сценічного простору може бути вистава «в салоні лімузину персонально для однієї сім'ї» (Пацунов, 2018, с.19). Тимчасового, нерухомого, дискретного, закритого, фронтального, експериментального, портативного сценічного простору - «моновистава в телефонній будці на фестивалі в Единбурзі [...], в планетарії під “зоряним небом" (Київський театр "Золоті ворота")» (Пацунов, 2018, с.19).

До експериментального можна зарахувати й спектакль «Яго» за В. Шекспіром Театру на Подолі (1994 рік, режисер В. Малахов), який свого часу підкорив Единбург - актори грали в старовинному вікторіанському басейні (Пацунов, 2018, с.19).

Світова пандемія COVID-19 спонукала діячів сцени до пошуків нових форм контакту з аудиторією, а відтак і до апробації нових форм сценічного простору. Так невелика трупа митців «Живи у вогні» (Vivre dans le feu) вирішила організувати низку пересувних оперних концертів «Концерт під твоїми вікнами» у дворах будинків. 3 метою дотримання санітарних карантинних вимог усі глядачі зали- 
шалися вдома та спостерігали за виступом музикантів зі своїх вікон. Декорації в стилі «грубого» театру, за Пітером Бруком, було спрощено до трьох різнокольорових килимків, рослин і піаніно, установлених посеред подвір'я. Учасники експериментального проєкту свідчать про успіх таких акцій серед глядачів, однак зауважують про незручності обмежень хронометражу виступів комендантською годиною та надмірну залежність від примх погоди - на деяких концертах доводилося виступати під дощем, а піаніно накривати брезентом чи парасолями (Fritel, 2021). Сценічний простір, що його освоюють французькі артисти, можна трактувати як сучасний варіант освоєння експериментального тимчасового, дискретного, відкритого, аренного або фронтального сценічного простору, оскільки історичний досвід виступів мандрівних артистів у дворах будинків простежується від зародження театрального мистецтва.

П. Брук (2008, с.683), досліджуючи питання театрального стилю, згадує свої післявоєнні враження, як у Гамбурзі, де було зруйновано всі театри, він «одного разу на горищі [...] бачив постановку “Злочин і кара", що залишила у пам'яті митця одне з найсильніших вражень». Актор, який сидів у кріслі й майже торкався колінами глядачів, напівінтимна манера акторського виконання, натуральна природа звуків створювали імерсійну атмосферу. Режисер свідчить: «Ми всі були залучені в драму» (Брук, 2008, с.683). Горище нагадувало Єлизаветинську сцену - «це була нейтральна відкрита платформа, просто майданчик з декількома дверима». Такий експериментальний сценічний простір надавав змогу режисерові «пропускати глядача через нескінченну низку різноманітних ілюзій», перенести у «Всесвіт актора і глядачів XVI століття». «Така сцена спрацьовувала, як чудова філософська машина», - зазначає П. Брук (2008, с.683).

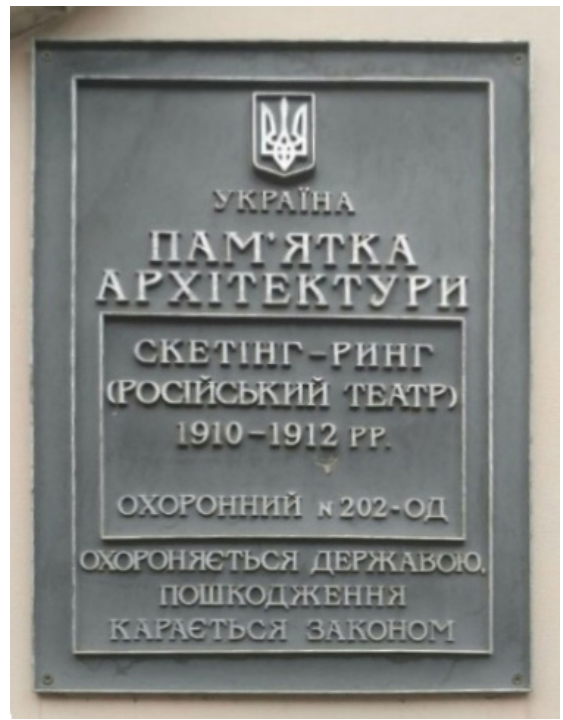

Рис. 2. Охоронна дошка на приміщенні

Одеського обласного академічного російського драматичного театру

(фото К. Юдової-Романової, 2018) 
Іноді традиційний сценічний простір можуть облаштовувати в непередбачених попередньо, тобто не спроєктованих для показу театрально-видовищних постановок приміщеннях. Це досить широкий спектр, починаючи від культових приміщень (готичний костел при монастирі францисканців було перетворено на перший у Львові стаціонарний театр (1787-1872), в якому було обладнано 36 лож, 114 крісел і по 200 місць у партері та галереї; театр у будівлі костелу перебував до середини XIX ст.), складів (для влаштування в Ярославні у 1750 році першого російського драматичного театру було обрано комору з кам'яними склепіннями, в якій зберігалися шкіряні товари; у коморі облаштували підмостки та місця для глядачів, обставили сцену декораціями, освітили комору плошками), скетінгрингу ${ }^{1}$ (Одеський обласний академічний російський драматичний театр, рис. 2.) і до перебудованих кінотеатрів (Київський академічний театр драми і комедії на лівому березі Дніпра, Київський академічний молодий театр та інші) та квартир. Наприклад, «Башенний театр» - назва декадентського театрального гуртка, заснованого письменником В. Івановим в Петербурзі, що існував у 1909-1910-х роках. Вистави влаштовували на квартирі В. Іванова, розташованій у верхній частині будинку - вежі (звідси й назва). Як видно на фото (рис. 3), сценічний простір цього театру можна трактувати як перенесення традиційної сцени-коробки в умови не спроєктованого під театр приміщення - квартири. Активним учасником гуртка був Всеволод Меєрхольд. Популярність «Башенний театр» здобув через спектакль «Поклоніння хресту» (1910 рік) П. Кальдерона (у пер. К. Д. Бальмонта; реж. Всеволод Меєрхольд, художник С. Ю. Судейкін).

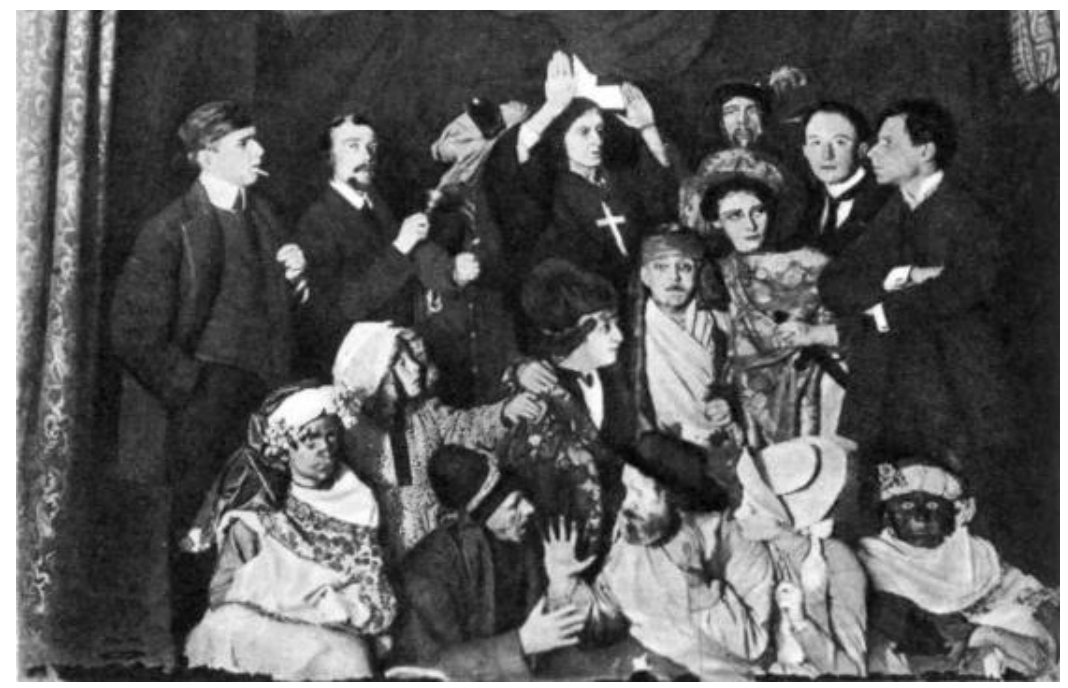

Рис. 3. Всеволод Меєрхольд (крайній праворуч)

з учасниками вистави «Поклоніння хресту» П. Кальдерона. «Башенний театр». Петербург. 1910 р. (Мейерхольд, 1968)

${ }^{1}$ Скетінг-ринг (англ. skating-ring) - спеціальний майданчик (частішев закритомуприміщенні) з гладкою асфальтованою підлогою для катання на особливих роликових ковзанах. 
Наукова новизна. Це дослідження є першою спробою класифікувати сучасний нетрадиційний сценічний простір. Оскільки сучасні театральні практики стрімко розвиваються в напрямку пошуку альтернативних сценічних майданчиків, безумовним постає питання подальшого поглибленого дослідження цієї проблематики як з боку театрознавців, так і архітекторів.

\section{Висновки}

3 огляду на сучасні театральні практики експериментальний сценічний простір відповідно до хронотопних його характеристик можна класифікувати таким чином:

- щодо незмінності розташування на території протягом сталого часу - постійний (стаціонарний) і тимчасовий;

- щодо переміщення у процесі показу вистави - рухомий (мобільний) і нерухомий;

- щодо розміщення глядачів і виконавців - імерсійний та дискретний;

- щодо форми сценічного простору - закритий і відкритий (просто неба);

- способу розміщення сценічного майданчика щодо публіки - фронтальний, аренний, подіумний.

В історії театральних приміщень часто трапляються випадки адаптації нетеатрального призначення будівель і навіть помешкань до показу вистав.

\section{СПИСОК ПОСИЛАНЬ}

Базанов, В.В., 2005. Технология сцены. Москва: Импульс-свет.

Березкин, В.И., 2011. От истоков до середины XX века. В: Искусство сценографии мирового театра. Москва: URSS.

Березкин, В.И., 2016а. Вторая половина XX века. В зеркале Пражских Квадриеннале 19671999 годов. В: Искусство сценографии мирового театра. Москва: Едиториал УРСС.

Березкин, В.И., 2016b. Мастера XVI-XX вв. В: Искусство сценографии мирового театра. Москва: Едиториал УРСС.

Брук, П., 2008. Пустое пространство. В: С.К. Никулин и Л.А. Пичхадзе, сост. Искусство режиссуры. XX век. Москва: Артист. Режиссер. Театр, с.623-730

Веселовська, Г.І., 2019. Театр як комунікативна система. В: Сценічне мистецтво у світовому культурному просторі XXI століття. Матеріали Всеукраїнської науково-практичної конференції. Київ, Україна, 19 квітня 2019. Київ: Київський національний університет культури і мистецтв, с.34-36.

Витрувий, 1936. Десять книг об архитектуре. [online] Доступно: <http://antique.totalarch. com/vitruvius> [Дата обращения 24 апреля 2021].

Извеков, Н.П., 1940. Техника сцены. Москва: Искусство.

Ленглі, С., 2000. Театральний менеджмент і продюсерство. Американський досвід. Київ: Компас.

Липський, О., 1985. Народний артист СРСР Костянтин Степанков та Валентин Шестопалов у виставі «Золоті ворота» Л. Горлача, Київський театр поезії. Український театр, 5.

Лідер, Д., 2004. Театр для себе. Київ: Факт. 
Мейерхольд, В.Э., 1968. Статьи письма речи беседы: Ч. 1. 1891-1917. [online] Москва: Искусство. Доступно: <https://refdb.ru/look/1021731-pall.html> [Дата обращения 24 апреля 2021]

Мочалов, Ю., 1981. Композиция сценического пространства. (Поэтика мизансцены). Москва: Просвещение.

Мы - команда. U!Zahvati, [online] Доступно: <https://uzahvati.com.ua/> [Дата обращения 10 апреля 2021].

Пацунов, В.П., 2018. Альтернативний сценічний простір як детонатор нової сценографічної лексики. В: Проблеми теорії і практики сценічного мистецтва XXI століття. Матеріали науково-практичної конференції професорсько-викладацького складу, аспірантів і магістрів. Київ, Україна, 19 квітня 2019. Київ: Київський національний університет культури і мистецтв, с.15-19.

Петров, А.А., 1903. Устройство театральной сцены. Санкт-Петербург: Типография Главного управления уделов.

Петров, А.А., 1910. Театральная техника с приложением правил устройств, оборудования и содержания театров. Санкт-Петербург: Типография Главного управления уделов.

Петров, А.А., 1925. Устройство и оборудование малых театральных сцен: городских, сельских и деревенских. Санкт-Петербург: Государственное издательство.

Проскуряков, В., 1986. Универсальные передвижные театры: (Принципы типологии ипроектирования). Диссертациякандидатанаук.Центральныйнаучно-исследовательский институт экспериментального проектирования жилища.

Проскуряков, В.І., 2001. Архітектура українського театру. Простір і дія. Львів: Львівська політехніка.

Проскуряков, В.І., 2002. Принципи розвитку архітектурної типології українського театру. Дисертація доктора архітектури. Національний університет "Львівська політехніка".

Ремез, О.Я., 1983. Мастерство режиссёра: Пространство и время спектакля. Москва: Просвещение.

Театр «Золоті ворота», 1993. «Калігула» А. Камю, режисер В. Пацунов, Київський театр «Золоті ворота»: сцени з вистави [фотоілюстрація]. Український театр, 1.

Френкель, М.А., 1987. Пластика сценического пространства: (Некоторые вопросы теории и практики сценографии). Киев: Мистецтво.

Эдкин, М.Г., 1974. О диапазоне пространственно-временных решений в искусстве оформления сцены (опыт анализа творческого наследия советской театральной декорации). В: Ритм, пространство и время в литературе и искусстве. Ленинград: Наука, с.209-219.

Экскузович, И.В., 2004. Об акустике в театре Макса Рейнхардта. Сцена, 5, с.35.

Юдова-Романова, К.В., 2016. Ольфакторна синестезія в сценічному мистецтві. Науковий вісник Київського національного університету театру, кіно і телебачення імені І. К. КарпенкаКарого, 19, с.29-36.

Юдова-Романова, К.В., 2017а. Пневматичні засоби конструювання сценічного простору. Вісник Національної академії керівних кадрів культури і мистецтв, 4, с.242-247.

Юдова-Романова, К.В., 2017b. Технічні засоби оформлення сценічного простору. Київ: Видавничий центр КНУКіМ.

Юдова-Романова, К.В., 2018а. Дизайн сценічного простору вогняними засобами конструювання. Вісник Національної академії керівних кадрів культури і мистецтв, 1, с.228-232. 
Юдова-Романова, К.В., 2018b. Засоби пластичного оформлення сценічного простору (з історії українського театру). Вісник Київського національного університету культури і мистецтв. Серія: Сценічне мистецтво, 2, с.72-92.

Fritel, L., 2021. Covid oblige, une troupe de musiciens se produit dans les cours d'immeubles. Le Figaro. [online] 03 March. Avialable at: <https://www.lefigaro.fr/musique/covid-oblige-unetroupe-de-musiciens-se-produit-dans-les-cours-d-immeubles-20210314>[Accessed 10 April 2021]

Furtenbach, J., 1663. Mannhaffter Kunst-Spiegel. Schultes. [online] Avialable at: <https://www.erara.ch/doi/10.3931/e-rara-8775> [Accessed 10 April 2021].

Furttenbach, J., 1628. Architectura Civilis. Saur. [online] Avialable at: <https://www.e-rara.ch/ doi/10.3931/e-rara-9950> [Accessed 10 April 2021].

Furttenbach, J., 1640. Architectura Recreationis, das ist, Von allerhand nutzlich und erfrewlichen civilischen Gebäwen. Schultes. [online] Avialable at: <https://www.e-rara.ch/doi/10.3931/erara-8866> [Accessed 10 April 2021].

McHenry, R., ed., 1997. Theatrical Production. The New Encyclopædia Britannica, 28, pp.554-608. Sabbattini, N., 1638. Pratica di fabricar scene e machine ne' teatri. - Ravenna: per Pietro de'Paoli, e Gio. Battifta Giouannelli Stampatori Camerali. [online] Avialable at: <https://archive.org/details/ praticadifabrica00sabb/page/168> [Accessed 10 April 2021].

Serlio, di S., 1600. Tutte l'opera d'Architettura di Sebastiano Serlio Bolognese Doue si trattano in disegno, quelle cose, che sono piu necessaire all'Architetto. Heredi di Francesco de' Franceschi. [online] Avialable at: <https://www.e-rara.ch/doi/10.3931/e-rara-370> [Accessed 10 April 2021].

\section{REFERENCES}

Bazanov, V.V., 2005. Tekhnologiia stceny [Scene technology]. Moscow: Impuls-svet.

Berezkin, V.I., 2011. Ot istokov do serediny XX veka [From the origins to the middle of the $\mathrm{XX}$ century]. In: Iskusstvo stcenografii mirovogo teatra [The art of scenography of the world theater]. Moscow: URSS.

Berezkin, V.I., 2016a. Vtoraia polovina XX veka. V zerkale Prazhskikh Kvadriennale 1967-1999 godov [The second half of the twentieth century. In the mirror of the Prague Quadrennial 19671999]. In: Iskusstvo stcenografii mirovogo teatra [The art of scenography of the world theater]. Moscow: Editorial URSS.

Berezkin, V.I., 2016b. Mastera XVI-XX vv [Masters of the 16th-20th centuries]. In: Iskusstvo stcenografii mirovogo teatra [The art of scenography of the world theater]. Moscow: Editorial URSS.

Bruk, P., 2008. Pustoe prostranstvo [Empty space]. In: S.K. Nikulin and L.A. Pichkhadze, comp. Iskusstvo rezhissury. XX vek [The art of directing. XX century]. Moscow: Artist. Rezhisser. Teatr, pp.623-730.

Edkin, M.G., 1974. O diapazone prostranstvenno-vremennykh reshenii v iskusstve oformleniia stceny (opyt analiza tvorcheskogo naslediia sovetskoi teatralnoi dekoratcii) [On the range of space-time solutions in the art of stage design (the experience of analyzing the creative heritage of Soviet theatrical scenery)]. In: Ritm, prostranstvo i vremia v literature $i$ iskusstve [Rhythm, Space and Time in Literature and Art]. Leningrad: Nauka, pp.209-219.

Ekskuzovich, I.V., 2004. Ob akustike v teatre Maksa Reinkhardta [About acoustics in the Max Reinhardt theater]. Stcena, 5, p.35. 
Frenkel, M.A., 1987. Plastika stcenicheskogo prostranstva: (Nekotorye voprosy teorii i praktiki stcenografii) [Plastics of the stage space: (Some questions of the theory and practice of scenography)]. Kyiv: Mistetctvo.

Fritel, L., 2021. Covid oblige, une troupe de musiciens se produit dans les cours d'immeubles. Le Figaro. [online] 03 March. Available at: <https://www.lefigaro.fr/musique/covid-oblige-unetroupe-de-musiciens-se-produit-dans-les-cours-d-immeubles-20210314>[Accessed 10 April 2021].

Furtenbach, J., 1663. Mannhaffter Kunst-Spiegel. Schultes. [online] Available at: <https://www.erara.ch/doi/10.3931/e-rara-8775> [Accessed 10 April 2021].

Furttenbach, J., 1628. Architectura Civilis. Saur. [online] Available at: <https://www.e-rara.ch/ doi/10.3931/e-rara-9950> [Accessed 10 April 2021].

Furttenbach, J., 1640. Architectura Recreationis, das ist, Von allerhand nutzlich und erfrewlichen civilischen Gebäwen. Schultes. [online] Available at: <https://www.e-rara.ch/doi/10.3931/erara-8866> [Accessed 10 April 2021].

ludova-Romanova, K.V., 2016. Olfaktorna synesteziia v stsenichnomu mystetstvi [Olfactory synesthesia in the performing arts]. Naukovyi visnyk Kyivskoho natsionalnoho universytetu teatru, kino i telebachennia imeni I. K. Karpenka-Karoho, 19, pp.29-36.

ludova-Romanova, K.V., 2017a. Pnevmatychni zasoby konstruiuvannia stsenichnoho prostoru [Pneumatic means of designing stage space]. National Academy of Managerial Staff of Culture and Arts Herald, 4, pp.242-247.

Iudova-Romanova, K.V., 2017b. Tekhnichni zasoby oformlennia stsenichnoho prostoru [Technical means of registration of stage space]. Kyiv: Vydavnychyi tsentr KNUKiM.

ludova-Romanova, K.V., 2018a. Dyzain stsenichnoho prostoru vohnianymy zasobamy konstruiuvannia [Design of stage space by fiery means of construction]. National Academy of Managerial Staff of Culture and Arts Herald, 1, pp.228-232.

ludova-Romanova, K.V., 2018b. Zasoby plastychnoho oformlennia stsenichnoho prostoru ( $z$ istorii ukrainskoho teatru) [Means of plastic design of stage space (from the history of Ukrainian theater)]. Bulletin of Kyiv National University of Culture and Arts. Series in Stage Art, 2, pp.72-92.

Izvekov, N.P., 1940. Tekhnika stceny [Scene technique]. Moscow: Iskusstvo.

Lenhli, S., 2000. Teatralnyi menedzhment i prodiuserstvo. Amerykanskyi dosvid [Theater management and production. American experience]. Kyiv: Kompas.

Lypskyi, O., 1985. Narodnyi artyst SRSR Kostiantyn Stepankov ta Valentyn Shestopalov u vystavi "Zoloti vorota" L. Horlacha, Kyivskyi teatr poezii [People's Artist of the USSR Konstantin Stepankov and Valentin Shestopalov in the play "Golden Gate" by L. Gorlach, Kyiv Poetry Theater]. Ukrainskyi teatr, 5.

Lider, D., 2004. Teatr dlia sebe [Theater for yourself]. Kyiv: Fakt.

McHenry, R., ed., 1997. Theatrical Production. The New Encyclopædia Britannica, 28, pp.554-608. Meierkhold, V.E., 1968. Stati pisma rechi besedy: Ch. 1. 1891-1917 [Conversation speech writing articles: Part 1. 1891-1917]. [online] Moscow: Iskusstvo. <https://refdb.ru/look/1021731-pall. html> [Accessed 10 April 2021].

Mochalov, lu., 1981. Kompozitciia stcenicheskogo prostranstva. (Poetika mizanstceny) [The composition of the stage space. (Poetics of mise-en-scène)]. Moscow: Prosveshchenie.

My - komanda [We are a team]. U!ZAHVATI. [online] Available at: <https://uzahvati.com.ua/> [Accessed 10 April 2021]. 
Patsunov, V.P., 2018. Alternatyvnyi stsenichnyi prostir yak detonator novoi stsenohrafichnoi leksyky [Alternative stage space as a detonator of new scenographic vocabulary]. In: Problemy teorii $i$ praktyky stsenichnoho mystetstva XXI stolittia [Problems of theory and practice of performing arts of the XXI century]. Proceedings of the scientific-practical conference of faculty, graduate students and masters. Kyiv, Ukraine, 19 April 2018. Kyiv: Kyiv National University of Culture and Arts, pp.15-19.

Petrov, A.A., 1903. Ustroistvo teatralnoi stceny [Theatrical stage arrangement]. St. Petersburg: Tipografiia Glavnogo upravleniia udelov.

Petrov, A.A., 1910. Teatralnaia tekhnika s prilozheniem pravil ustroistv, oborudovaniia i soderzhaniia teatrov [Theatrical technique with the application of the rules for the devices, equipment and maintenance of theaters]. St. Petersburg: Tipografiia Glavnogo upravleniia udelov.

Petrov, A.A., 1925. Ustroistvo i oborudovanie malykh teatralnykh stcen: gorodskikh, selskikh $i$ derevenskikh [The device and equipment of small theater stages: urban, rural and rural]. Moscow: Gosudarstvennoe izdatelstvo.

Proskuriakov, V., 1986. Universalnye peredvizhnye teatry: Printcipy tipologii i proektirovaniia [Universal traveling theaters: Principles of typology and design]. Ph.D. thesis. Tcentralnyi nauchno-issledovatelskii institut eksperimentalnogo proektirovaniia zhilishcha.

Proskuriakov, V.I., 2001. Arkhitektura ukrainskoho teatru. Prostir i diia [Architecture of the Ukrainian theater. Space and action]. Lviv: Lvivska politekhnika.

Proskuriakov, V.I., 2002. Pryntsypy rozvytku arkhitekturnoi typolohii ukrainskoho teatru [Principles of development of the architectural typology of the Ukrainian theater]. PhD Dissertation. Natsionalnyi universytet "Lvivska politekhnika".

Remez, O.la., 1983. Masterstvo rezhissera: Prostranstvo i vremia spektaklia [Director's skill: Space and time of the performance]. Moscow: Prosveshchenie.

Sabbattini, N., 1638. Pratica di fabricar scene e machine ne' teatri. - Ravenna: per Pietro de'Paoli, e Gio. Battifta Giouannelli Stampatori Camerali. [online] Available at: <https://archive.org/details/ praticadifabrica00sabb/page/168> [Accessed 10 April 2021].

Serlio, di S., 1600. Tutte l'opera d'Architettura di Sebastiano Serlio Bolognese Doue si trattano in disegno, quelle cose, che sono piu necessaire all'Architetto. Heredi di Francesco de' Franceschi. [online] Available at: <https://www.e-rara.ch/doi/10.3931/e-rara-370> [Accessed 10 April 2021].

Teatr "Zoloti vorota", 1993. "Kalihula" A. Kamiu, rezhyser V. Patsunov, Kyivskyi teatr "Zoloti vorota": stseny z vystavy ["Caligula" by A. Camus, directed by V. Patsunov, Kyiv Theater "Golden Gate": scenes from the play] [photo illustration]. Ukrainskyi teatr, 1.

Veselovska, H.I., 2019. Teatr yak komunikatyvna systema [Theater as a communication system]. In: Stsenichne mystetstvo u svitovomu kulturnomu prostori XXI stolittia [Performing Arts in the world cultural space of the XXI century], Proceedings of the All-Ukrainian scientific-practical conference. Kyiv, Ukraine, 19 April 2019. Kyiv: Kyiv National University of Culture and Arts, pp.34-36. Vitruvii, 1936. Desiat knig ob arkhitekture [Ten books on architecture]. [online] Available at:<http:// antique.totalarch.com/vitruvius> [Accessed 10 April 2021]. 


\title{
ЭКСПЕРИМЕНТАЛЬНОЕ СЦЕНИЧЕСКОЕ ПРОСТРАНСТВО: ПРОБЛЕМЫ КЛАССИФИКАЦИИ
}

\section{Екатерина Юдова-Романова}

кандидат искусствоведения, доцент;

e-mail: iudovakateryna@gmail.com; ORCID: 0000-0003-2665-390X

Киевский национальный университет культуры и искусств, Киев, Украина

\begin{abstract}
Аннотация
Цель статьи - исследовать, охарактеризовать и классифицировать экспериментальные варианты организации сценического пространства. В процессе исследования были применены следующие методы научного познания: метод анализа и синтеза информации, культуролого-искусствоведческий метод (для установления связи между вариантами формы сценического пространства и художественно-образным решением спектакля), а также исторический (для изучения фактов из истории театра) и сравнительный (для определения общих и отличительных характеристик с целью классификации сценического пространства). Метод синтеза и анализа информации был использован для детального изучения и дальнейшего анализа опыта реализации театральных представлений в экспериментальном сценическом пространстве. Благодаря сочетанию анализа и синтеза обеспечивается комплексный системный подход к изучению предмета исследования - сценического пространства. В процессе исследования были проанализированы литературные источники отечественных и зарубежных авторов по тематике работы. Научная новизна. Осуществлена классификация современного экспериментального сценического пространства по основным хронотопным характеристикам. Выводы. Исходя из фактологического анализа современных театральных практик, экспериментальное сценическое пространство в соответствии с его временными и пространственными характеристиками можно классифицировать следующим образом: относительно неизменности расположения на территории в течение значительного времени - постоянный (стационарный) и временный; относительно перемещения в процессе показа спектакля - подвижной (мобильный) и неподвижный; по размещению зрителей и исполнителей - иммерсионный и дискретный; по форме сценического пространства - закрытый и открытый (под открытым небом); по способу размещения сценической площадки относительно публики - фронтальный, аренный, подиумный. Висториитеатральныхпомещенийвстречаютсяотдельныеслучаиадаптации зданий нетеатрального назначения и даже жилых помещений к показу спектаклей.
\end{abstract}

Ключевые слова: экспериментальное сценическое пространство; альтернативное сценическое пространство; нетрадиционное сценическое пространство; сцена; театр; классификация 


\title{
EXPERIMENTAL STAGE SPACE: PROBLEMS OF CLASSIFICATION
}

\section{Kateryna ludova-Romanova}

Ph.D. in Art History, Associate Professor;

e-mail: iudovakateryna@gmail.com; ORCID: 0000-0003-2665-390X

Kyiv National University of Culture and Arts, Kyiv, Ukraine

\begin{abstract}
The purpose of the article is to investigate, characterize and classify experimental variants of stage space organization. The following methods of scientific knowledge have been used in the research process: method of analysis and synthesis of information, cultural and art method (to establish a connection between the variants of the form of the stage space and the artistic and figurative solution of the performance), as well as historical (to study the facts of the history of the theater) and comparative (to determine common and different characteristics in order to classify the stage space). The method of synthesis and analysis of information is used for detailed study and further analysis of the experience of theatrical performances in the experimental stage space. Due to the combination of analysis and synthesis, a comprehensive systematic approach to the study of the research subject is stage space. In the course of the research the literary sources of domestic and foreign authors on the subject of work have been analyzed. Scientific novelty. The classification of modern experimental stage space according to the main chronotopic characteristics has been carried out. Conclusions. Given the factual analysis of modern theatrical practices, experimental stage space according to its temporal and spatial characteristics can be classified as follows: regarding the invariability of the location on the territory for a permanent time is permanent (stationary) and temporary; regarding the movement in the process of showing the play is movable (mobile) and immovable; regarding the placement of spectators and performers is immersive and discrete; regarding the shape of the stage space is closed and open (open air); way of placing the stage in relation to the audience is front, arena, podium. In the history of theater premises there are many cases of adaptation of non-theatrical buildings and even apartments to show performances.
\end{abstract}

Keywords: experimental stage space; alternative stage space; non-traditional stage space; scene; theater; classification 